\title{
Dynamic case study of phytoplankton as a result of the non- biological characteristics of water at Embaba Drinking Water Station, Giza
}

\author{
A.D. El-Gamal ${ }^{1}$, I.M.M. Barakat ${ }^{2}$, H.A.S. Hassan ${ }^{3}$ and R.A. Salah El Din ${ }^{4 *}$ \\ 1. Botany and Microbiology Department, Faculty of Science, Al-Azhar University (Boys). \\ 2. Biologist in central lab of Giza Company for water and wastewater, Holding Company \\ for water and wastewater \\ 3. Botany Department, Faculty of Science, Fayoum University, Fayoum, Egypt. \\ 4. Botany and Microbiology Department, Faculty of Science, Al-Azhar University (Girls \\ Branch).
}

\begin{abstract}
:
The results showed that water treatment negatively affected the concentration of turbidity, hydrogen ion concentration, total hardness and magnesium hardness, while concentrations were not changed or were close due to the processes of water treatment for both electrical conductivity and total dissolved salts and calcium hardness in comparison of the Nile samples and expulsion for these parameters. The result of water treatment has been fruitful in reducing concentrations or clearing concentrations of ammonia, nitrite and nitrates. The results confirmed that water treatments did not affect the various cations such as sodium, potassium, calcium, magnesium, aluminum, iron and manganese.

Aluminum cation may have increased as a result of the use of aluminum sulphate in water treatment.

Phytoplankton count in row and treated water from Embaba Drinking Water Treatment Plant was recorded in both Nile water and treated ones where the highest count was 2396000 and the lowest was 1818999 Unit/L in the case of row water while the highest results were $195334 \mathrm{Unit} / \mathrm{L}$ and the lowest results were $30000 \mathrm{Unit} / \mathrm{L}$ in the case of treated water, respectively. Phytoplankton composition was belonged to Bacillariophyceae, Cyanophyceae and Chlorophyceae groups. The dominant diatoms were Cyclotella spp. and Melosira spp., while blue-greens were dominated by Gomphosphaeria aponina and Merismopedia tenuissima. Green algae were dominated by Ankistrodesmus falcatus and Coelastrum microporum.
\end{abstract}

Keywords: Phytoplankton, Water Treatment Plant, River Nile, Chlorophyceae, Cyanophyceae, diatoms, Nile samples, treated samples. 


\section{Introduction}

The main water resource in Egypt is the River Nile, which originates in Lake Tanganyika at latitude $3^{\circ} \mathrm{S}$, passing northward through several African countries to the shore of the Mediterranean Sea in Egypt at latitude $31^{\circ} 15 \mathrm{~N}$ (Zahran, and Willis, 2003).

The global trend toward eutrophication of drinking water supplies has increased especially on the negative effects of algae on water treatment processes. In particular, the addition of oxidants such as chlorine, ozone, or permanganate to untreated water prior to coagulation has been shown to increase the removal of algae (Plummer and Edzwald, 2002; Chen and Yeh, 2005). These oxidants alter the surface charge of algae and thus improving their removal during coagulation (Daly et al., 2007).Generally, chlorine disinfection effectively depends on the applied dose and contact time (Casey et al., 2012).

A typical drinking water treatment system in Egypt comprises stages of pre-chlorination, flocculation/coagulation with alum, filtration, post-chlorination, and settling in distribution tanks (Donia, 2007). In this set-up, pre-chlorination is regarded as the most important stage for the control of algal growth (Donia, 2007; Badawy et al., 2012).

After the completion of the Aswan High Dam in 1966, stream-flow regulation has caused significant changes to the Nile aquatic ecosystem and waterway environment (El-Shinnawy et al., 2000; Talling $\boldsymbol{e t}$ al., 2009). This change in flow led to the retention of water masses in reservoirs behind dams and barrages in some regions within the Nile system, which provided favorable conditions and ample time for phytoplankton development. Subsequently, this altered the aquatic vegetation which is a source of nutrients for phytoplankton and algae utilization.

Shehata et al. (2008) reported that with regards to the total algal counts before and after High Dam construction, it may be shown that the total algal 
counts in the river Nile water increased one tenfold after construction impoundment.

Regardless of the damage caused by algae in the Nile River, but by controlled them and follow their growth can be used to convert atmospheric carbon dioxide into biomass, fatty acid and lipids (Spolaore et al., 2006). Microalgae are easy to culture, characterized by rapid growth and are able to grow in waters, unsuitable in some cases, for human consumption. Moreover, they can grow anywhere, their rate of growth depends on sunlight and simple nutrients, as well as to certain specific compounds and appropriate aeration (Aslan and Kapdan, 2006; Frac et al., 2010; Verma $\boldsymbol{e t}$ al., 2010).The current study is a follow - up of Embaba Water Treatment Plant for drinking water and comparison of water produced before and after treatment in terms of physical and chemical properties and phytoplankton count.

\section{Materials and Methods}

\section{Samples collection}

Samples were taken from Embaba water treatment plant (WTP), from one of each of the following: (Nile intake), and taps (out take). Samples were monthly collected from November, 2013 to November, 2014.

\section{Physical and Chemical properties:}

Turbidity, Electrical conductivity (EC) and Total Dissolved Salts (T.D.S.), Free Residual $\mathrm{Cl}_{2}\left(\mathrm{FR} \mathrm{Cl}_{2}\right)$, pH Value, Total Hardness (T.H.):as mg $\mathrm{CaCO}_{3} / \mathrm{L}$, Calcium Hardness (Ca H.), Magnesium Hardness (Mg H.), Alkalinity, Chloride, Ammonia, Nitrite, Nitrate, Sulfate and Heavy Metals by Inductively Coupled Plasma/Optical Emission Spectrometry (ICP-OES) were measured using (APHA et al., 2005). 
The phytoplankton was preserved in Lugol's solution according to the method describe by (APHA et al., 2005), and was calculated using SedgwickRafter cell.

Identification of algal taxa was carried out according to Prescott (1982) and Patrick and Reimer, (1966 and 1975); Jensen, (1985); Krammer and Lang-Bertalot, (1986, 1988); Round et al. (1990).

\section{Statistics Analyses:}

Correlation and regression using SPSS (statistical package for the social sciences) to link the relationships between all physical and chemical properties of water (Nie et al., 1975).

The matrix of phytoplankton and physical, chemical properties were subjected to canonical corresponding analysis using PC-ORD 5 program.

\section{Results and Discussion}

\section{Physical and Chemical properties of Nile water from Embaba (WTP):}

Turbidity of a natural body of water is an important determinant of its condition and productivity. Where, turbidity in water body known as all suspended particles being present in water. As water becomes more turbid, less sunlight is able to penetrate its surface, therefore the amount of photosynthesis that can occurs decreases. The present results (Table 1) shows that turbidity values ranged between (2.97 and 30.70 NTU) in Nile sample with average of (9.11 NTU), while in treated water the turbidity was between (0.3 and 1.18 NTU) with average of (0.63 NTU). Also, it varied from month to month with maximum peak (30.7 NTU) in May and the lowest value (2.97 NTU) in February. Turbidity is the measure of total suspended matter in water, mostly dependent on many 
factors as temperature and the water conditions such as waste disposal or flooding. Turbidity may be as a result to clay, silt, organic matter, inorganic matter, microscopic organisms and similar materials contribute to turbidity level (Abd El-Shakouret al., 2012). The present data revealed that the highest water turbidity was observed in spring period whilst the lowest value was in winter season.

The lower values of turbidity were always associated with are remarkable drop in total standing crop and increase in turbidity parallel to conspicuous increases in phytoplankton populations(El-Attar, 2000).

El-Dars et al. (2015) reported that the highest water turbidity was observed during the winter period while the lowest was during the summer season, this may be related to the water closure period. High turbidity of the Nile stream was attributed to the increase in water nutrient content (Emara et al., 2012). The turbidity was dramatically reduced due to drinking water treatment and was average between 0.3-1.18 NTU. Also, Mahmoud et al. (2016) reported that the turbidity values of treated water sampled was 1 NTU.

The results of current electrical conductivity in either Nile or treated water samples were not significantly affected. The measurement of EC were different between Nile water and treated water samples as follows, where the results as in table (1) were between $258-492 \mu \mathrm{S} / \mathrm{cm}$ and average was $396 \mu \mathrm{S} / \mathrm{cm}$ in Nile water. In treated water the EC ranged from $260-510 \mu \mathrm{S} / \mathrm{cm}$ with average was $410 \mu \mathrm{S} / \mathrm{cm}$. The current results were similar with those attained by El-Otify and Iskaros (2015) who stated that in winter, slightly high EC values were recorded as compared to the other seasons the value between 230.83 and $269.33 \mu \mathrm{S} / \mathrm{cm}$. Mahmoud et al. (2016) reported that the EC of treated water samples was 410.9 $\mu \mathrm{S} / \mathrm{cm}$ in tap water and $424.6 \mu \mathrm{S} / \mathrm{cm}$ in Nile water. Total Dissolved Solids (TDS) is a measure of the inorganic dissolved salts and small amounts of organic matter present in a sample of water. In TDS analysis, the results show in table (1) were slight different between Nile water and treated water samples, where, it was between 170 - $325 \mathrm{mg} \backslash \mathrm{L}$ with average of $261 \mathrm{mg} \backslash$ Lin Nile water. On the other hand, in treated water the TDS ranged from 172 - $337 \mathrm{mglL}$ with average of 271 $\mathrm{mglL}$.

Egyptian J. of Phycol. Vol. 20, 2019 


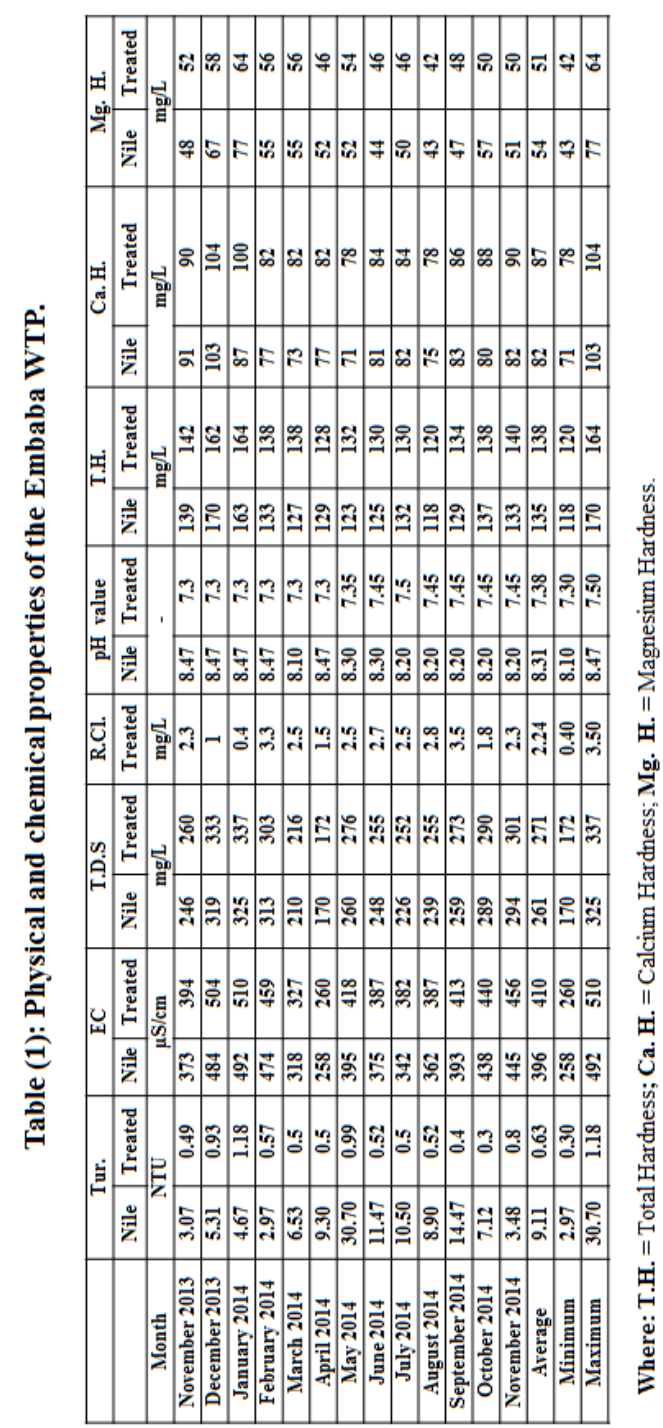


Ali et al. (2014) showed slight variations throughout the sampling segment of the Nile. An obvious increase in TDS was however, recorded at (El-Nasria) during April (318.0 mg/L) and June (524.0 mg/L) during season 2011. Amer and Abd El-Gawad (2012) reported that the salinity of Nile water increased going from Aswan High Dam $(160 \mathrm{mg} / \mathrm{L})$ to Cairo (around $260 \mathrm{mg} / \mathrm{L}$ ). Wahaab and Badawy (2004) and Talling (2009) reported that higher TDS recorded during winter for the Nile waters was attributed to the dam closure period in which the amount of water released from the behind the dam was less than that in summer. Water EC is the direct function of its total dissolved salts (Harilal $\boldsymbol{e t}$ al., 2004) and is used as an index to represent the total concentration of soluble salts in water (Purandara et al., 2003; Gupta et al., 2008). The present TDS values were not affected by significant change either before treatment in raw water or after treatment of drinking water. This means that the soluble salts of the treated water are not disposed of and this requires more domestic measures to use this water. Mahmoud et al. (2016) reported that the TDS value of treated water samples was $243.8 \mathrm{mg} / \mathrm{L}$ and $260.5 \mathrm{mg} / \mathrm{L}$ in Nile water.

Overall, the efficiency of the pre-chlorination stage is governed by two indicators, namely: the chlorine demand and residual chlorine content. The chlorine demand determines the chlorine dose applied during the pre- chlorination /disinfection process and the residual chlorine signifies that sufficient amount of chlorine has been added to inactivate bacteria and some viruses that may cause diarrheal disease in drinking water (WHO, 2011). Residual chlorine was found between 0.4 and $3.5 \mathrm{mg} \backslash \mathrm{L}$ with average of $2.24 \mathrm{mg} \backslash \mathrm{L}$ table (1). Mahmoud $\boldsymbol{e t}$ al. (2016) reported that residual chlorine values of treated water samples were 1.9 $\mathrm{mg} / \mathrm{L}$. Technically, a minimum of $0.5 \mathrm{mg} / \mathrm{L}$ residual chlorine must be maintained to ensure water protection from recontamination during storage and that residual chlorine levels between 0.2 and $0.5 \mathrm{mg} / \mathrm{L}$ at the consumer outlet water given the extremities of the supply network (WHO, 2011).

Measurement of $\mathrm{pH}$ is one of the most important and frequently used tests in water chemistry. The $\mathrm{pH}$ of a water body is very important in determination of water quality since it affects other chemical reactions such as solubility and metal 
toxicity (Agbaire and Obi, 2009). Practically every phase of water supply and wastewater treatment, e.g., acid-base neutralization, water softening, precipitation, coagulation, disinfection, and corrosion control, is $\mathrm{pH}-\mathrm{dependent.}$

The $\mathrm{pH}$ values were slightly alkaline with a range of $8.31,7.38$ in both raw and treated water, respectively table (1). Alaa and Werner (2010) reported that results of $\mathrm{pH}$ seem to be constant all over the river Nile and all $\mathrm{pH}$ values were in alkaline side. Ali $\boldsymbol{e t}$ al. (2014) also recorded that with regards to $\mathrm{pH}$, determined $\mathrm{pH}$ values showed a tendency towards alkaline side, with no clear seasonal changes during their study period. However, a sudden decrease in $\mathrm{pH}$ value (7.44) was recorded at El- Nasria during June 2011.Mahmoud et al. (2016) reported that $\mathrm{pH}$ values of water samples ranges from 7.6 in tap water.

Originally, water hardness was understood to be a measure of the capacity of water to precipitate soap. Calcium and magnesium in water cause hardness. Total hardness is defined as the sum of calcium and magnesium concentrations. Alaa and Werner (2010) recorded that water hardness was slightly increased from Aswan to Rosetta and Damietta reaching the highest value at Rosetta (162.3 ppm). They noticed that $\mathrm{Ca}$ and $\mathrm{Mg}$ nearly have the same distribution as water hardness. From table (1) Total hardness was measured in Nile sample between 118 and $170 \mathrm{mglL}$ with average was $135 \mathrm{mgL}$ while the total hardness was between 120 and $164 \mathrm{mg} \backslash \mathrm{L}$ with average was $138 \mathrm{mg} \backslash \mathrm{L}$ in treated water. The highest value of calcium and magnesium hardness were 103 and $77 \mathrm{mglL}$ respectively in the Nile water samples, where, it was 104 and $64 \mathrm{mglL}$ respectively in treated water samples, while the lowest value was 71 and $43 \mathrm{mg} \backslash \mathrm{L}$ in the case of Nile water and78 and $42 \mathrm{mgL}$ in treated water samples. Ali et al. (2014) also recorded that hardness refers to the concentration of calcium and magnesium in water with hard water possesses high concentrations of these elements. Total hardness in their study at different segments of Nile ranged from 41.15 to $111.18 \mathrm{mg} \mathrm{CaCO}_{3} / \mathrm{L}$. The present results took the same trend i.e. the hardness linked to hardness of calcium and magnesium hardness. Mahmoud $\boldsymbol{e t}$ al. (2016) reported that the total hardness values of treated water samples were 127.9 
$\mathrm{mglL}$ and $\mathrm{Ca}$ hardness values of treated water samples were $85.1 \mathrm{mg} \mathrm{L}$, but $\mathrm{Mg}$ hardness values of treated water samples were $56.3 \mathrm{mg} \backslash \mathrm{L}$.

Alkalinity is a measure of water's ability to neutralize acids. In most types of water, alkalinity is the result of bicarbonates $\left(\mathrm{HCO}_{3}\right)$, carbonates $\left(\mathrm{CO}_{3}{ }^{2-}\right)$, and hydroxides $\left(\mathrm{OH}^{-}\right)$of the metals calcium, magnesium, and sodium.

Alkalinity as in table (2) revealed that the highest values of alkalinity (177 and 148) were recorded, where the lowest values (115 and 108) were recorded in both Nile and treated water samples, respectively. Alaa and Werner (2010) described alkalinity as an indication of the concentration of carbonate, bicarbonate and hydroxide content in water. Alkalinity was fluctuated within a very narrow ranges recording highest values at Rosetta $(124.3 \mathrm{mg} / \mathrm{L})$ followed by Damietta $(115.2 \mathrm{mg} / \mathrm{L})$.) Ali et al. (2014) also recorded that alkalinity is produced by the existence of minerals such as limestone $\left(\mathrm{CaCO}_{3}\right)$. Total alkalinity showed distinctive variations throughout the sampling period with regards to time. In any case, the current results show variations between results in different months and this is consistent with previous results. The results confirmed that the alkalinity had decreased in the treated samples of drinking water and was between 108-148 $\mathrm{mg} / \mathrm{L}$. Mahmoud et al. (2016) reported that the total alkalinity values of treated water samples were $118.7 \mathrm{mg} / \mathrm{L}$.

Chloride, in the form of chloride $\left(\mathrm{Cl}^{-}\right)$ion, is one of the major inorganic anions in water. The salty taste produced by chloride concentrations is variable and dependent on the chemical composition of water. Sulfate ion $\left(\mathrm{SO}_{4}{ }^{2-}\right)$ is precipitated in an acetic acid medium with barium chloride $\left(\mathrm{BaCl}_{2}\right)$ so as to form barium sulfate $\left(\mathrm{BaSO}_{4}\right)$ crystals of uniform size.

For Chloride and Sulfate ions it was observed that as in table (2) the maximum values ( 47 and $84 \mathrm{mglL}$ ) were recorded in treated water samples compared to that recorded in (43 and $66 \mathrm{mgL}$ ) in Nile water samples, respectively. 


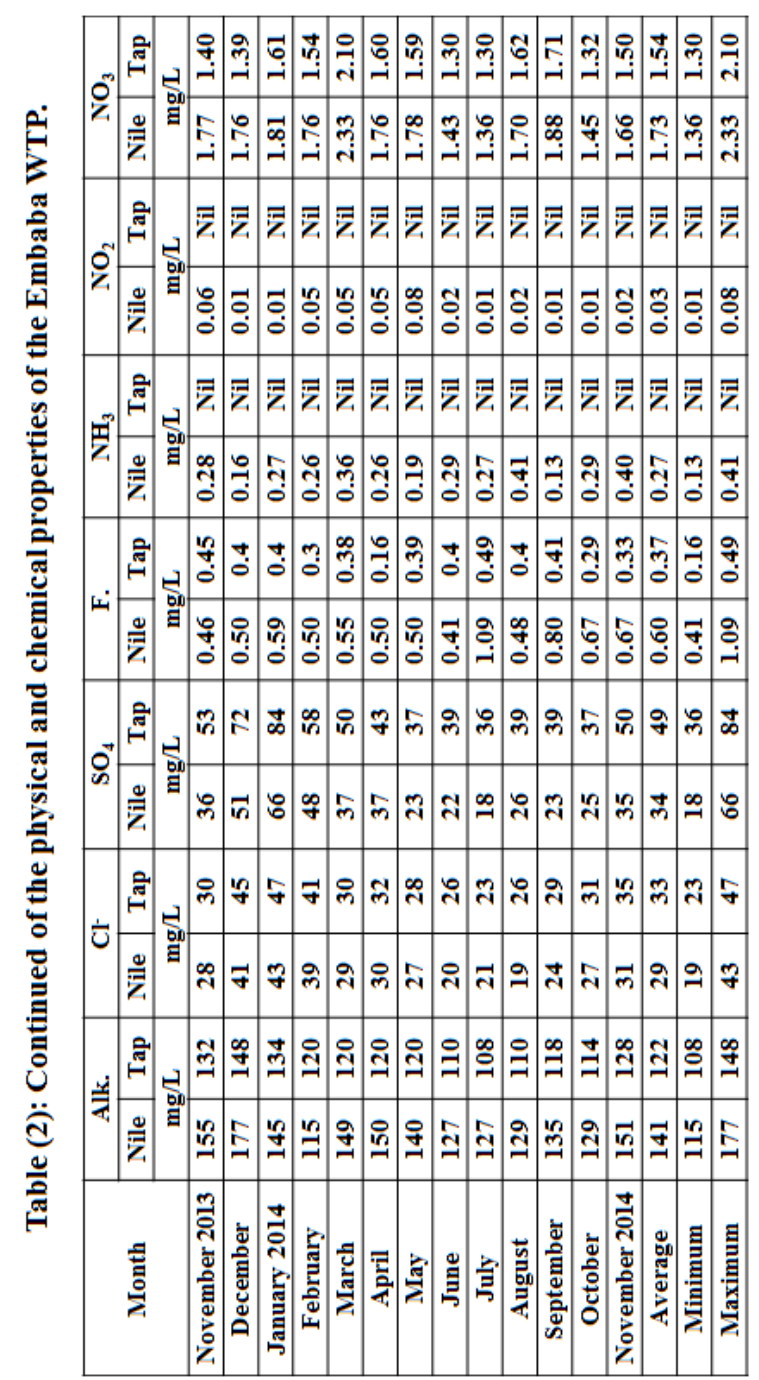


Alaa and Werner (2010) recorded that chloride is the most common inorganic anion found in water and wastewater. The distribution of $(\mathrm{Cl})$ was similar to those of the cations ( $\mathrm{Ca}$ and $\mathrm{Mg}$ ) showing a minor increase from Aswan to Damietta and Rosetta.

According to El-Otify and Iskaros (2015) sulfate did not exhibit wide range of variations among the investigated sites. In winter and spring, levels of sulphate were somewhat lower than those in summer and autumn and the value between 8.56 and $14.06 \mathrm{mg} / \mathrm{L}$. Ali et al. (2014) also recorded that the high levels of sulphate are the result of the excessive use of sulphate-rich fertilizers as well as the domestic wastes (Emara et al., 2016). Mahmoud et al. (2016) reported that the $\mathrm{Cl}$ values of treated water samples were $25.6 \mathrm{mg} / \mathrm{L}$. also, reported that the $\mathrm{SO}_{4}$ values of treated water samples were $31.8 \mathrm{mg} / \mathrm{L}$.

Fluoride occurs naturally in public water systems as a result of runoff from weathering of fluoride-containing rocks and soils and leaching from soil into groundwater. Concentrations of fluorides ranged from 0.41 to 1.09 and 0.16-0.49 $\mathrm{mg} / \mathrm{L}$ in both Nile and water treated samples table (2). According to the present results fluoride did not have a specific tendency to increase or decrease concentrations during study. Mahmoud et al. (2016) reported that the treated water samples have F concentration was $0.26 \mathrm{mg} / \mathrm{L}$.

For the results of concentrations of ammonia and nitrite, the results showed a lack of concentrations of the two parameters as the results confirmed the effectiveness of water treatment methods in the disposal of these concentrations. Nitrate Concentrations ranged from 1.3 to 2.1 in treated water samples table (2).

\footnotetext{
Alaa and Werner (2010) recorded that ammonia is excreted by animals and produced during decomposition of plants and animals, thus returning nitrogen to the aquatic system. Ammonia was recorded in a very low concentration in all sites recording the highest value at Rosetta $(0.14 \mathrm{mg} \backslash \mathrm{L})$. Nitrate is often the limiting element restricting biological productivity of Nile water (Chapman and 
Chapman, 1996). The values of nitrate fluctuated within a wide range and showed low levels during the whole period of investigation. The highest value of nitrate was recorded at Rosetta. Higher concentration of nitrate in water of Rosetta branch can create a large oxygen demand and cause algae to grow in large quantity.

Mahmoud et al. (2016) reported that the $\mathrm{NO}_{2}$ values of treated water samples were under detection limits (UDL). Also, reported that the $\mathrm{NO}_{3}$ values of treated water samples were $1.2 \mathrm{mg} / \mathrm{L}$.

To evaluate the performance of WTPs, all results of treated water were compared to permissible limits of drinking water in Egypt as mentioned in the Egyptian law and decision of the Ministry of Health No. 458/2007; such limits are identical to the international standard of world health organization (WHO, 2011). With the increased turbidity, alum sulphate is used in high concentration and this may explain the recorded increase of $\mathrm{Al}$ in some month in two WTPs. $\mathrm{Al}$ as a harmful neurotoxic metal that may induce Alzheimer's disease must be allowed to precipitate completely as Al hydroxide (Schutte, 2006).

Essential and heavy metals were recorded in table (3). Sodium concentration varied in different months of study, ranging from $22.2-47.87 \mathrm{mg} \backslash \mathrm{L}$ with an average of $32.702 \mathrm{mg} \backslash \mathrm{L}$ in Nile water samples. In treated water samples, $\mathrm{Na}$ concentration ranged from $23-47.73 \mathrm{mg} \backslash \mathrm{L}$, with an average of $32.652 \mathrm{mg} \backslash \mathrm{L}$. Potassium concentrations were less than sodium at concentration ranging from 4.92 - $5.82 \mathrm{mg} \backslash \mathrm{L}$ with an average of $5.502 \mathrm{mg} \backslash \mathrm{L}$ in Nile water samples. In treated water samples, $\mathrm{K}$ concentration ranged from $4.97-5.84 \mathrm{mglL}$, with an average of $5.505 \mathrm{mg} \backslash \mathrm{L}$.

Calcium is the most reactive cations present in water, the decrease in calcium is directly associated with the utilization of $\mathrm{CO}_{2}$ in photosynthesis process (Abo El-Lil, 2003).

Egyptian J. of Phycol. Vol. 20, 2019

$-166-$ 


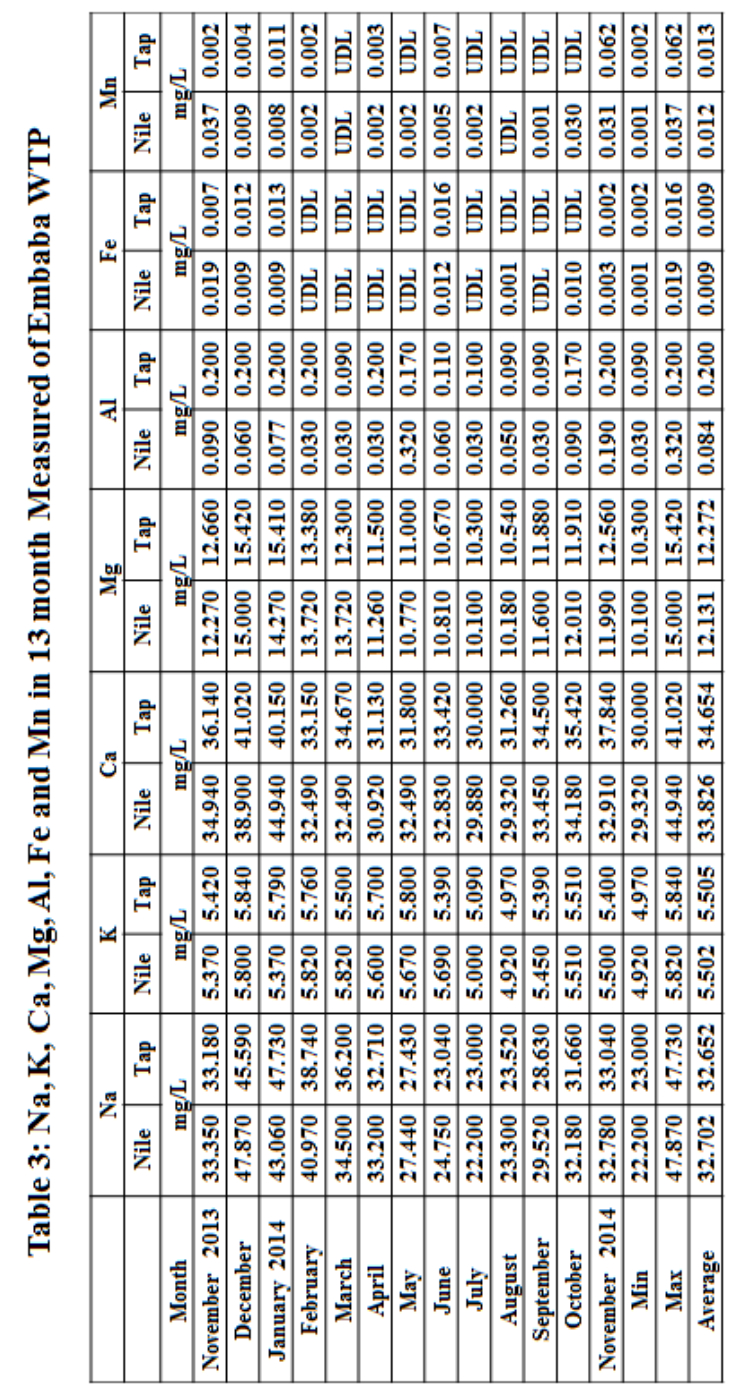


Also, Verma et al. (2011) classified water bodies into: (i) poor (ii) medium and (iii) rich water body with regard to calcium content. Calcium concentration varied in different months of study, ranging from $29.32-44.94 \mathrm{mg} \mathrm{L}$ with an average of $33.82 \mathrm{mg} L$ in Nile water samples. In treated water samples, calcium concentration ranged from $30-41.02 \mathrm{mglL}$, with an average of $34.654 \mathrm{mg} \backslash \mathrm{L}$.

This harmonized with the discovery of (Awadallah and Soltan, 1995; Abdel-Satar, 2005) which they concluded that the lowest values of $\mathrm{Ca}$ were recorded in the hot seasons and the highest in the cold seasons. This might be due to the decrease in the solubility of $\mathrm{CaCO}_{3}$ as the temperature increase. This was achieved by a negative correlation existed between calcium and water temperature during autumn and summer.

Magnesium concentrations were less than sodium and calcium at concentration ranging from $10.1-15 \mathrm{mgL}$ with an average of $12.131 \mathrm{mg} \backslash \mathrm{Lin}$ Nile water samples. In treated water samples, $\mathrm{Mg}$ concentration ranged from 10.3 - $15.42 \mathrm{mgL}$, with an average of $12.272 \mathrm{mg} \backslash \mathrm{L}$. In addition, the preferential behavior of dissolved $\mathrm{CO}_{2}$ may affect the concentration of magnesium in solution, when $\mathrm{CO}_{2}$ present in appreciable concentration it reacts with calcium salts than with magnesium, thus converting large quantities of calcium into soluble bicarbonates (Abdel-Satar, 2005).

For iron and manganese ions, the values were minimal and there were near constant values before and after treatment.

Al Aluminum salts are used in water treatment as coagulants to reduce organic matter, color, turbidity and microorganisms levels (WHO, 2010). The levels of $\mathrm{Al}$ is high or low of treated water in Nile water that may be related to low demand period or high aluminum dose in water plants. Salim (2012) reported that total iron ranged between 0.002 to $0.86 \mathrm{mg} \backslash \mathrm{L}$ in raw water at New Mansoura and Bilqlas WTP. He also reported that total manganese concentrations ranged 
between 0.004 and $0.55 \mathrm{mg} \backslash \mathrm{L}$ and the higher values of total iron and total manganese were recorded in colder season of winter.

Mahmoud et al. (2016) reported that the $\mathrm{Al}$ values of treated water samples were $0.3 \mathrm{mg} / \mathrm{L}, \mathrm{Fe}$ values of treated water samples were $0.1 \mathrm{mg} / \mathrm{L}$ and Mn values of treated water samples were $0.1 \mathrm{mg} / \mathrm{L}$.

An over view to the present investigation the elements were record an increased in winter compared to summer at Nile water. Also, comparison of the Nile samples and expulsion for the elements it was clear that the concentration of sodium, calcium, magnesium, iron, manganese and potassium change by increases and decreases according to the season, while the concentration of aluminum it increase with larger proportions in treated water by adding alum (aluminum sulfate) and chlorine practical of coagulation, sedimentation and filtration.

From Table 4, there were statistical relations with positive values at level of 0.01 between turbidity and concentration of hydrogen ion, nitrite and nitrates and positive relationship between electrical conductivity and TDS, $\mathrm{TH}, \mathrm{Ca} \mathrm{H}, \mathrm{Mg}$ $\mathrm{H}, \mathrm{Cl}, \mathrm{SO}_{4}, \mathrm{Na}, \mathrm{Ca}$, and $\mathrm{Mg}$.

Also, a positive relation between TDS and $\mathrm{TH}, \mathrm{Ca} \mathrm{H}, \mathrm{Mg} \mathrm{H}, \mathrm{Cl}, \mathrm{SO}_{4}, \mathrm{Na}$, $\mathrm{Ca}$, and $\mathrm{Mg}$. Total turbidity was associated with partial turbidity of $\mathrm{Ca} \mathrm{H}$ and $\mathrm{Mg}$ $\mathrm{H}$ as well as alkalinity, $\mathrm{SO}_{4}, \mathrm{Na}, \mathrm{Ca}$ and $\mathrm{Mg}$. Ammonia was generally associated with nitrite, nitrates, and vice versa in positive relationships. In considering negative relationships $\mathrm{R}$ chlorine has been associated with negative relations with turbidity, $\mathrm{pH}$, alkalinity, $\mathrm{NH}_{3}, \mathrm{NO}_{2}, \mathrm{NO}_{3}$ and $\mathrm{F}$. 


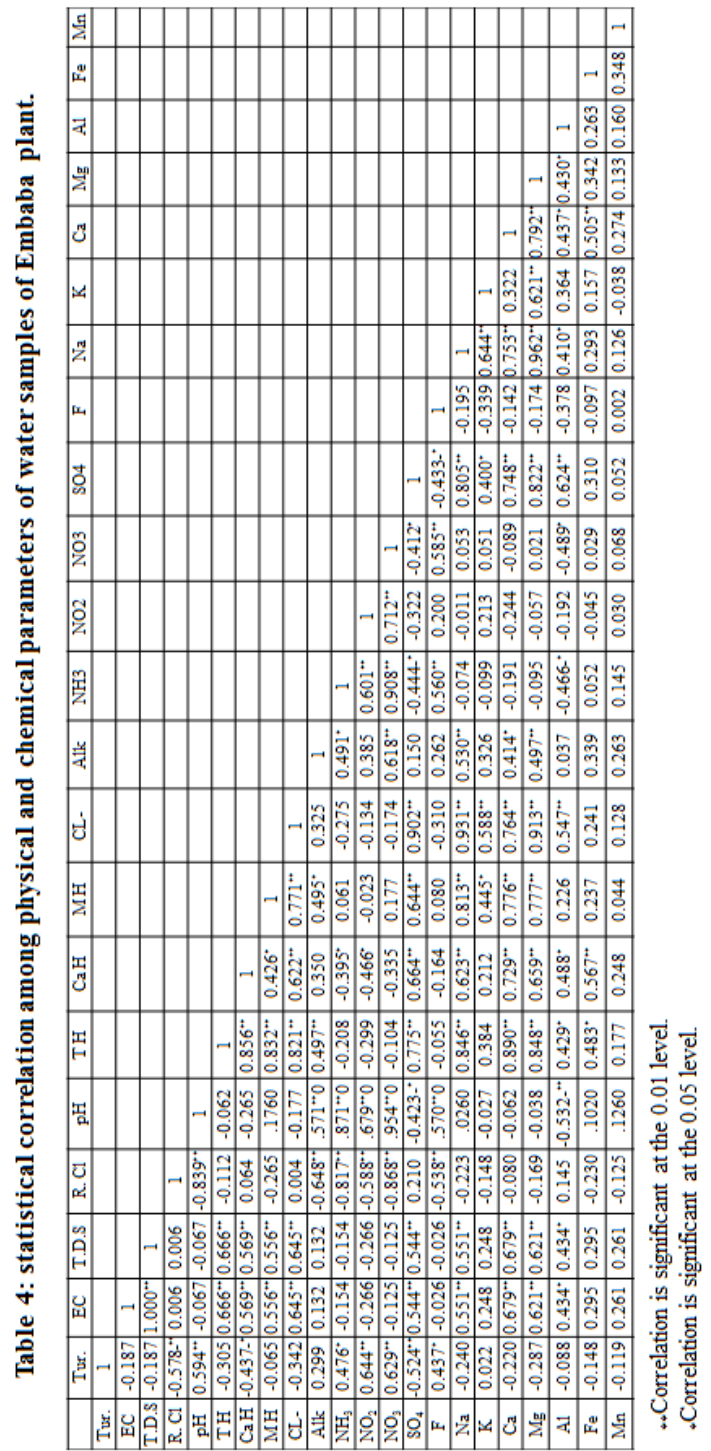


Phytoplankton is typically the main primary producer in any ecosystem. Microscopic analysis of algae in collected water sample showed that they belong to three main divisions. Bacillariophyta, Chlorophyta and Cyanophyta as reported by (Shehata et al. 2009; Ali, 2010). The current results confirmed the dominance of Bacillariophyceae compared to other divisions where the total Bacillariophyta count in Nile water samples ranged between 745333-1704000unit/L the most numerical common genera were Cyclotella, Melosira and Synedra, while the lowest numerical presence were Asterionella, Fragilaria and Navicula the average of count was 1182590 unit/L. On the other side total Bacillariophyta count ranged from 6667 - 45333 unit/L in treated water samples with average 24103 unit/L. followed by total Chlorophyta count in Nile water samples ranged between 778667 - 328000 unit/L with dominate genera of Ankistrodesmus falcatus and Scenedesmus quadricauda, the average of count was 572308 unit/L. On the other side, total Chlorophyta count ranged from 11333 - 106667 unit/L in treated water samples with average 37554 unit/L. Finally total Cyanophyta count in Nile water samples ranged between 90667 - 464000 unit/L with dominate genera of Merismopedia tenuissima then Gomphosphaeria aponina, the average of count was 275231 unit/L. On the other side total Cyanophyta count ranged from 3333 80667 unit/L in treated water samples with average 31282 unit/L, the finally total count in Nile water samples ranged between 2396000 - 1818999 unit/L with the average was 2030128 unit/L. Where, the treated water samples total count ranged from 195334 - 30000unit/L with average 92938unit/L table (5).

The Present results were in consistency of the results found by Shehata $e t$ al. (2009) who reported that diatoms were the most dominant and diversified group present in good numbers during four seasons especially in fall and winter seasons followed by green algae. Blue-green algae were presented in small number during different seasons. Among the diatoms, Cyclotella comta was the most dominant throughout the year, other important centric diatoms was Melosira granulata. Pinnate diatoms were dominated by Diatomae longatum and Synedra ulna. 
Table 5: Phytoplankton total count during study period.

\begin{tabular}{|c|c|c|c|c|c|c|c|c|}
\hline & \multicolumn{2}{|c|}{ Total Chlorophyta } & \multicolumn{2}{|c|}{ Total Cyanophyta } & \multicolumn{2}{|c|}{$\begin{array}{c}\text { Total } \\
\text { Bacillariophyta }\end{array}$} & \multicolumn{2}{|c|}{ Total count } \\
\hline & Nile & Treated & Nile & Treated & Nile & Treated & Nile & Treated \\
\hline & \multicolumn{8}{|c|}{ Average Unit/L } \\
\hline $\begin{array}{c}\text { November } \\
2013\end{array}$ & 568000 & 106667 & 226667 & 50000 & 1232000 & 38667 & 2026667 & 195334 \\
\hline December & 610667 & 64667 & 238667 & 71333 & 1182667 & 28000 & 2032001 & 164000 \\
\hline January 2014 & 698000 & 31533 & 358000 & 15333 & 1084000 & 6667 & 2140000 & 53533 \\
\hline February & 533333 & 40667 & 202667 & 14000 & 1262667 & 10667 & 1998667 & 65334 \\
\hline March & 778667 & 65333 & 330667 & 28667 & 1001333 & 17333 & 2110667 & 111333 \\
\hline April & 555333 & 29333 & 145333 & 62667 & 1118333 & 10000 & 1818999 & 102000 \\
\hline May & 557333 & 27333 & 401333 & 80667 & 881333 & 45333 & 1839999 & 153333 \\
\hline June & 676667 & 34000 & 464000 & 21333 & 745333 & 22000 & 1886000 & 77333 \\
\hline July & 603333 & 20667 & 417333 & 15333 & 936000 & 23333 & 1956666 & 59333 \\
\hline August & 585333 & 18000 & 192000 & 9333 & 1135333 & 37333 & 1912666 & 64666 \\
\hline September & 446667 & 11333 & 90667 & 3333 & 1585333 & 32000 & 2122667 & 46666 \\
\hline October & 498667 & 12667 & 146667 & 6000 & 1505333 & 11333 & 2150667 & 30000 \\
\hline $\begin{array}{c}\text { November } \\
2014\end{array}$ & 328000 & 26000 & 364000 & 28667 & 1704000 & 30667 & 2396000 & 85334 \\
\hline Average & 572308 & 37554 & 275231 & 31282 & 1182590 & 24103 & 2030128 & 92938 \\
\hline Min & 328000 & 11333 & 90667 & 3333 & 745333 & 6667 & 1818999 & 30000 \\
\hline Max & 778667 & 106667 & 464000 & 80667 & 1704000 & 45333 & 2396000 & 195334 \\
\hline
\end{tabular}

In general terms, the diatoms found are characteristic of eutrophic water bodies and most are recorded as halophytic which preferring alkaline waters (Wolf, 1982), which correspond to the conditions of relative high $\mathrm{pH}$ in the river Nile. El-Dars et al. (2015) reported that a higher algal count was obtained during the period from Sept. to Nov. 2012. This increase may be attributed to agricultural wastewater discharge and the accumulation of pollutants and nutrients south of the sampling point. While, Shehata $\boldsymbol{e t}$ al. (2009) showed that clear variability was found in total algal numbers during different investigated seasons. The algal counts ranged from 2246 to $21245 \mathrm{Org}$. / $\mathrm{ml}$ with maximum attained during fall and winter seasons dominated with species belonging to diatoms which favorite low temperature. Current results were consistent with results of Shehata $\boldsymbol{e t}$ al. (2009) who reported that the green algae were dominated by small planktonic 
Chlorococcales belonging to the genera; Scenedesmus, Ankistrodesmus, Botroyococcus and Dictyoshaerium. Cyanophyta rarely grew to significant concentration except during periods of high temperature in spring and summer seasons. The numbers of genera or species of Nile water algae that are responsible for causing serious problems in water works are relatively high. Some genera of diatoms are significant in this respect and certain green algae and blue-green algae are also important. The present results showed that the percentage reduction in the number of Cyanophyceae was $88.6 \%$ and reduction of the number of green algae was $93.4 \%$, while the number of diatoms was reduced to $98 \%$, while the total decrease in the number of phytoplankton was $95.4 \%$. This confirms the important role that water treatment plays in the mechanical or chemical elimination of algae populations. Swanepoel $\boldsymbol{e t}$ al. (2017) showed that when high concentrations of Cyanophyceae (> 100000 cells. $\mathrm{mL}^{-1}$ ) occur in the raw water, $>2000$ cells. $\mathrm{mL}^{-1}$ of the same or smaller Cyanophyceae species (e.g. Cylindrospermopsis raciborskii and Merismopedia sp.) penetrate into the drinking water. This in return, opens the field for the search for modern technological methods for the complete elimination of these algae during the treatment of drinking water. Our results confirmed the presence of numbers of algae found in drinking water after the process of drinking water treatment.

Abdel-hamid et al. (2012) reported that under optimum performance of coagulation process, the removal of the rest suspended algae by granular media may reach $99.99 \%$. Where, Mahmoud et al.(2016) reported that the total alga count in treatment water was 531 organism /L.

In the present investigation, the application of canonical corresponding analysis (CCA) indicated the presence of an ecological relationship between the phytoplankton community (as group) and its surrounding habitats.

CCA between phytoplankton groups and physical and chemical characteristics of water was illustrated in Fig. (1). It illustrates the correlation between abundance of different phytoplankton groups and the environmental variables. It was clear that total count and diatoms count were positive correlated with turbidity, EC and TDS. On the other hand, the Cyanophyta count was positive correlated with $\mathrm{R}$. Cl. but Chlorophyta was positive correlated with 
hardness, sulphate, alkalinity and chloride and negatively correlated with other parameters. Khafagy et al. (2018) reported that Chlorophyta and Cyanophyta were positively correlated with ammonia, EC, total alkinilty, chlorides, hardness and sulphate. Also diatoms were positively correlated with turbidity.

Also, the correlation between abundance of different phytoplankton groups and the heavy metal concentrations (CCA) was studied Fig. (2). It revealed that diatoms were positive correlated with Mn. On the other hand, Cyanophyta was positive correlated with $\mathrm{K}$ and $\mathrm{Al}$. But Chlorophyta was positive correlated with $\mathrm{Ca}, \mathrm{Mg}, \mathrm{Na}$ and $\mathrm{Fe}$ and total count was negatively correlated with all elements.

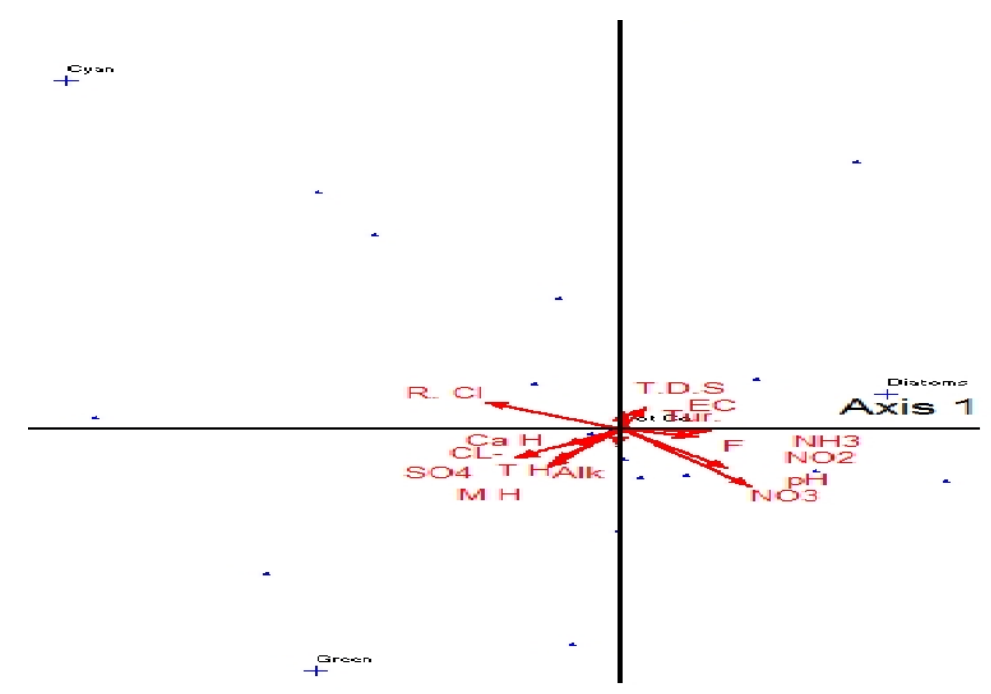

Fig 1: Canonical Corresponding Analysis (CCA) of physical and chemical characteristics and phytoplankton groups. 


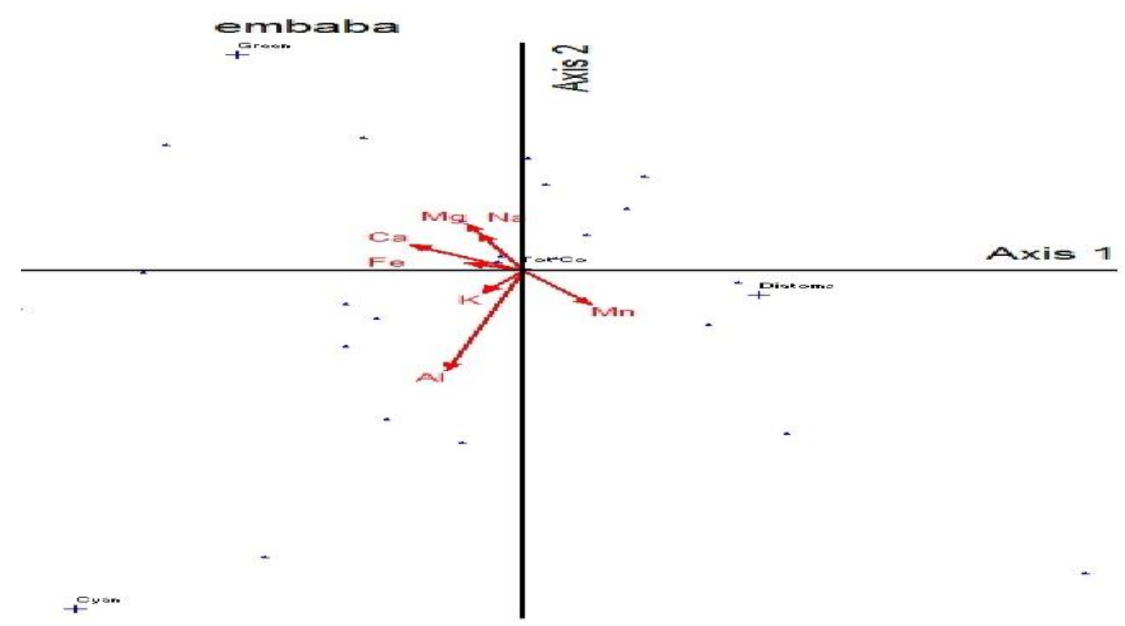

Fig 2: Canonical Corresponding Analysis (CCA) of heavy metal and phytoplankton group.

\section{References}

Abd El-shakour, E. H., Ezzat, S. M.,Mahdy, H. M., Abo-State, M. A. and Mostafa, A. (2012). Water quality assessment of River Nile at Rosetta Branch: impact of drain discharge. Middle-east Journal of Scientific Research, 12(4): 413-423.

Abdel-Hamid, M. I.; Hussein, M. H. and Elshafey, S. S. (2012).Efficiency assessment of different drinking water treatment plants based on water physico-chemical characteristics, removal of the suspended algae and toxicity assessment with standard algal bioassay. The Egyptian Society of Experimental Biology, (Botany), 8(1): 1 - 15.

Abdel-Satar, Amal M. (2005).Water Quality Assessment of River Nile from Idfo to Cairo.Egyptian Journal of Aquatic Research,31(2):200-223. 
Abo El-lil, A.H. (2003).Evaluation the Ecological Impacts due to Unique Torrent Phenomenon on Aquatic Ecosystem (River Nile, Cairo, Egypt).Online Journal of Biological Sciences,3(2):197-203.

Agbaire, P.O. and Obi, C.G. (2009).Seasonal Variations of Some PhysicoChemical Properties of River Ethiope Water in Abraka, Nigeria.Journal of Applied Science and Environmental Management,13(1):55-57.

Alaa, G. M. O. and Werner, K. (2010). Water quality and heavy metal monitoring in water, sediments, and tissues of the African catfish clariasgariepinus (burchell, 1822) from the River Nile, Egypt. Journal of Environmental Protection, 2010(1):389-400.

Ali E. N. (2010). Application of Moringa seeds extract in water treatment. $P h D$ thesis; department of biotechnology engineering, International Islamic university, Kuala Lumpur, Malaysia.

Ali, E. M.; Sami, A. Sh. D.; Abdel, R. I. S. and Ahlam, S. E. (2014).Characterization of chemical water quality in the Nile River, Egypt.International Journal of Pure and Applied Bioscience, 2(3): 35-53.

Amer, A. S. and Abd El-Gawad, H. A. (2012).Rapid bio-indicators assessment of macrobiotic pollution on aquatic environment. International Water Technology Journal,2(3), 196- 206.

APHA-AWWA-WPCF (2005): Standard methods for the examination of water and wastewater, $21^{\text {th }}$ ed. American Public Health Association, American Water Works Association and Water Pollution Control Federation, Washington, DC.

Aslan, S. and Kapdan, I. K. (2006).Batch kinetics of nitrogen and phosphorus removal from synthetic wastewater by algae, Ecology Engineer. 28(1): 64-70.

Awadallah, R.M. and Soltan, M.E. (1995).Environmental, Physical and Chemical Changes of Lake Nubia-Aswan High Dam Lake Water.Journal of Environmental Science and Health, Part A: Environmental Science and Engineering and Toxicology,30(9):2071-2087.

Egyptian J. of Phycol. Vol. 20, 2019 
Badawy, M. I., Gad-Allah, T. A., Ali, M. E. M. and Yoon, Y. 2012).Minimization of the formation of disinfection byproducts. Chemosphere89(3): 235-240.

Casey, T., Kearney, P. and Kerr, H. (2012). The chlorine demandcharacteristics of Irish water supplies: process designimplications for disinfection and THM Formation. Chartered Institution of Water and Environmental Management, London.http://www. engineersireland. iel Engineers Ireland/media/SiteMedia/groups/societies/water-enviro/Chlorine-

Demand-Characteristics-of-Irish-Water-Supplies.pdf?ext=.pdf (accessed 11 April 2015).

Chapman, D. and Chapman, D. E. E. d. (1996).water quality assessments - A guide to the use of biota, sediments and water in environmental Monitoring. $2^{\text {nd }}$ Edition, Chapman and Hall, London.609 p.

Chen, J. J. and Yeh, H. H. (2005). The mechanisms of potassium permanganate on algae removal. Water Research, 39 (18): 4420-4428.

Daly R. I., lionel H. and Brookes J. D.(2007). Effect of Chlorination on Microcystisaeruginosa Cell Integrity and Subsequent Microcystin Release and Degradation. Environmental Science and Technology, 41 (12): 44474453.

Donia, N. (2007).Survey of potable water quality problems in Egypt.In: Proceedings of Eleventh International Water TechnologyConference, IWTC11 2007 Sharm El-Sheikh, Egypt,pp. 1049-1058.

El-Attar, S.A. (2000).Changes in Physico-chemical Characters and Phytoplankton Structure of El-Salam Canal in the West of Suez Canal Region.Egyptian Journal of Phycology, 1:1-13.

El-Dars, F. M. S., Abdel Rahman, M. A. M, Salem, O. M. A. and AbdelAal, E. A. (2015). Algal control and enhanced removal in drinking waters in Cairo, Egypt: A case study. Environmental Science an Indian Journal (ESAIJ), 10(8):295-307. 
El-Otify, A. M. and Iskaros,I. A. (2015).Water quality and potamoplankton evaluation of the Nile River in Upper Egypt. Acta Limnologica Brasiliensia, 27(2): 171-190.

El-Shinnawy, I. A., Abdel-Meguid, M., Nour Eldin, M. M. and Bakry, M. F. (2000). Impact of Aswan High Dam on the aquatic weedecosystem.In: Proceedings of ICEHM2000, Cairo University, Egypt, pp. 534-541.

Emara, E. K. M., Farfour, S. A. and Ibrahim E. M. (2016).Environmental Studies on the Effects of Aquaculture and Drainage Wastewaters on Lake Burullus. American-Eurasian Journal Agriculture and Environmental Sciences.16 (2): 410-423

Emara, M. M.; Farag, R. S.; Sorour, S. and Sabry, Z. W. (2012). Assessment the efficiency of conventional water treatment and direct filtration on drinking water quality based on seasonal change in physic-chemical characteristics of raw Nile water. Journal of Applied Sciences Research, 8(1), 57-64.

Frac, M.; Jezierska-Tys, S., and Tys, J. (2010). Microalgae for biofuels production and environmental applications: A review. African Journal of Biotechnology, 9(54): 9227-9236.

Gupta, S.; Maheto, A.; Roy, P.; Datta, J. K. and Saha, R. N. (2008).Geochemistry of groundwater Burdwan district, West Bengal India. Environ. Geol., 53: 1271-1282.

Harilal, C. C.; Hashim, A.; Arun, P. R. and Baji, S (2004).Hydro geochemistry of two rivers of Kerala with special reference to drinking water quality.Journal of Ecology Environment Conserve, 10(2):187-192.

Jensen, N. G. (1985). The Pennate Diatoms. A translation of Hustedt's "Die Kieselalgen, 2. Teil." Koeltz Scientific Books, Koenigstein, 918 pp.

Khafagy, D. H. A. (2018). Biochemical monitoring and evaluation of some drinking plants and application of new biotechnology for water treatment.PhD. Thesis department of botany, faculty of sciences, Tanta university. Pp 205 
Krammer, K. and Lange-Bertalot, H. (1986). Bacillariophyceae. 1. Teil:Naviculaceae. In: Süsswasserflora von Mitteleuropa. Band 2/1. H. Ettl; J. Gerloff; H. Heynig and D. Mollenhauer (eds.).Gustav Fisher Verlag, Stuttgart, 876 pp.

Krammer, K. and Lange-Bertalot, H. (1988). Bacillariophyceae. 2. Teil: Bacillariaceae, Epithemiaceaeand Surirellaceae. In: Süsswasserflora von Mitteleuropa. Band 2/2. H. Ettl; J. Gerloff; H. Heynig and D. Mollenhauer (eds.). Gustav Fisher Verlag, Stuttgart, 821 pp.

Mahmoud, H. M.; Mohamed, E. A.;Khalil, M. H. and Mahgoub M. S. (2016). Comprehensive performance assessment of the potable water treatment plants in El Fayoum governorate, Egypt. Journal of Pharmaceutical, Biological and Chemical Sciences: (0975-8585): 2189-2213

Nie, N., Bent, D., HULL, C., Jenkins, J., Steinbrenner, K. and Bent, D. (1975).SPSS:statistical package for the social sciences, New York: McGraw-Hill.

Patrick, R. and Reimer, C. W. (1966). The diatoms of the United States (Exclucive of Alaska and Hawaii). Vol. 1: Fragilariaceae, Eunotiaceae, Achnanthaceae, and Naviculaceae. Monogrs. Acad. Sci. Philad. 13: 688 pp.

Patrick, R. and Reimer, C. W. (1975). The diatoms of the United States (Exclucive of Alaska and Hawaii). Vol.2, Part 1: Entomoneidaceae, Cymbellaceae, Gomphonemaceae, and Epithemiaceae. Monogrs. Acad. Sci. Philad. 13: 213 pp.

Plummer, J. D. and Edzwald, J. K. (2002).Effects of chlorine and ozone on algal cell properties and removal by coagulation. Journal of Water Supply: Research and Technology Aqua, 51 (6):307-318.

Prescott, G. W. (1982).Algae of the western great lakes area with an illustrated key to genera of desmids and fresh water diatoms.Ottokoeltz science puplishers.977 P.

Purandara, B. K.; Varadarajan, N. and Jayashree K.(2003).Impact of sewage on ground water: a case study. Poll Res, 22(2):189-197. 
Round, F. E., Crawford, R. M. and Mann, D. G. (1990). The diatoms: biology and morphology of the genera. Cambridge University Press, Cambridge, 747 pp.

Salim, E. H. (2012). Investigation on microalgae and cyanotoxins in surface raw and drinking water, M. Sc. thesis, Botany Department, Faculty of Science, Mansoura University. Mansoura, Egypt, 219 P.

Schutte, F. (2006). Handbook for the operation of water treatment works. The Water Research Commission, the Water Institute of Southern Africa.233 .

Shehata S. A.; Ali G. H. and Wahba S.Z. (2008). Distribution pattern of Nile water algae with reference to its treatability in drinking water, Journal of Applied Sciences Research, 4(6):722-730.

Shehata, S. A.; Badr, S. A.; Ali, G. H.; Ghazy, M. M.; Moawad, A. K. and Wahba, S. Z. (2009). Assessment of Nile water quality via phytoplankton changes and toxicity bioassay test. Journal of Applied Sciences Research, 5(12): 2083-2095.

Spolaore, P.; C.Joannis-Cassan, E. and Duran, A. (2006).Commercial applications of microalgae. Isambert, Journal of Bioscience and Bioenginering (101): 87-96.

Swanepoel, A., Du Preez, HH and Cloete, N. (2017): The occurrence and removal of algae (including cyanobacteria) and their related organic compounds from source water in Vaalkop Dam with conventional and

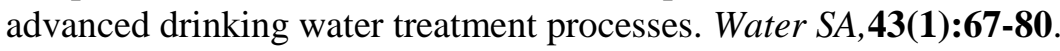

Talling, J. F. (2009). Physical and chemical water characteristics. In 'The Nile: Origin, Environments, Limnology and human use', Monographiaebiologicae 89, H. J. Dumont (Ed), Springer Science + Business Media B.V., Netherlands, 367-394.

Talling, J. F., Sinada, F., Taha, O. E. andSobhy, E. M. H. (2009).Phytoplankton: composition, development and productivity. In: The Nile: Origin, Environments, Limnology and Human Use (H. J. Dumont, ed.). Springer Science +Business Media B.V., The Netherlands, .431-462. 
Verma, N.M.; S. Mehrotra, A.; Shukla, B. N. and Mishra, A. J. (2010). Review: Prospective of biodiesel production utilizing microalgae as the cell factories: A comprehensive discussion. African Journal of Biotechnology, 9(10):1402-1411.

Verma, P.U.; Chandawat, D.K. and Solanki, H.A. (2011).Seasonal Variation in Physico-chemical and Phytoplankton Analysis of Kankaria Lake. Life Sciences Leaflets, 19:842-854.

Wahaab, R. A. and Badawy, M. I. (2004).Water quality assessment of the river Nile system: An overview. Biomedical and Environmental Sciences, (17): 87-100.

WHO (World Health Organization), (2011).Guidelines for Drinking-water Quality, Fourth edition. Volume 1, Recommendations. In: WHO (World Health Organization) WHO, Geneva.

Wolf, H. (1982). Methods of coding of ecological data from diatoms for computer utilization .Model Rijks. Geol. Dienst, 36(2): 95-110.

Zahran, M. A. and Willis,A. J. (2003).Plant Life in the River Nile in Egypt. MARS Publishing House. 


\title{
دراسة الحالة الديناميكية للهائمات كنتيجة للصفات الغيربيولوجية للمياه في محطة إمبابة لمياه الثرب، جيزة المصنمة
}

\author{
أحمد درويش الجمل' ،إبراهيم بركات ‘حنان عبد الله سعيد حسان “،روحية عبد اللطيف صلاح

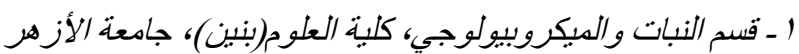

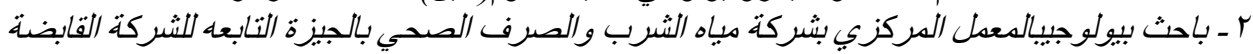

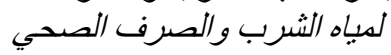

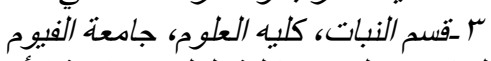 \\ ع ـ قسم النبات والمبكروبيولوجي، كلبة العلوم، جامعة الأزهر(فرع النبات
}

أظهرت النتائج أن معالجة مباه الثرب أثرت سلبا على تركيز درجة العكارة ، تركيز أيون

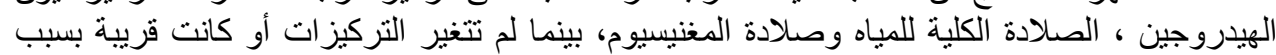

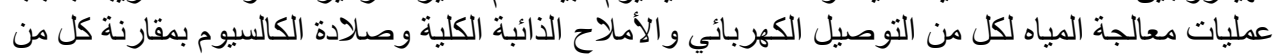

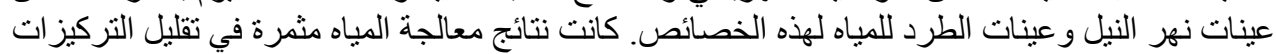

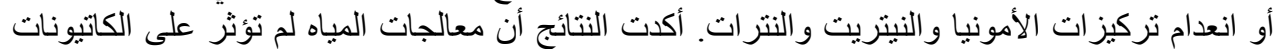

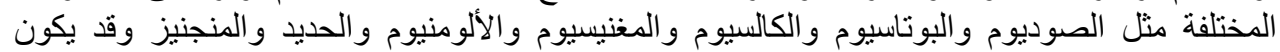

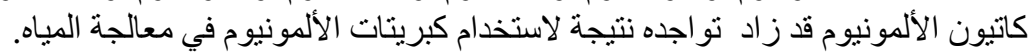

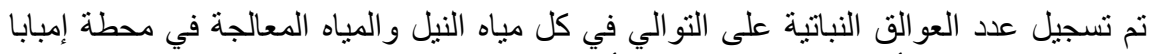

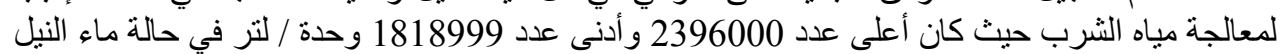

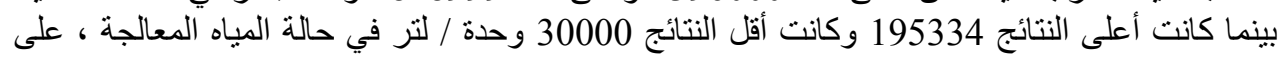

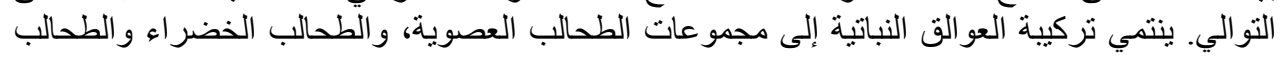

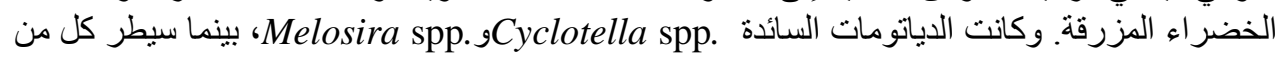

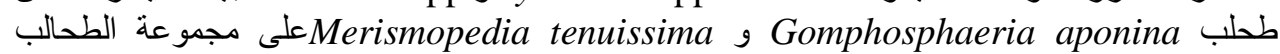
الخضراء المزرقه. وكانت مجموعة الطحالب الخضراء يهيمن عليها كل من Ankistrodesmus

.Coelastrum microporum g falcatus 